\title{
First offshore observation of parti-coloured bat Vespertilio murinus in the Belgian part of the North Sea
}

\author{
Robin Brabant ${ }^{1, *, \dagger}$, Yves Laurent ${ }^{2, \dagger}$, René-Marie Lafontaine ${ }^{2}$, \\ Bob Vandendriessche ${ }^{3}$ \& Steven Degraer ${ }^{1}$
}

\footnotetext{
1 Royal Belgian Institute of Natural Sciences (RBINS), Operational Directorate Natural Environment (OD Nature), Aquatic and Terrestrial Ecology (ATECO), Marine Ecology and Management (MARECO), Gulledelle 100, 1200 Brussels, Belgium.

2 Royal Belgian Institute of Natural Sciences (RBINS), Operational Directorate Natural Environment (OD Nature), Aquatic and Terrestrial Ecology (ATECO), Conservation Biology, Rue de Vautier 29, 1000 Brussels, Belgium.

3 Natuurpunt Studie vzw, Vleermuizenwerkgroep. Coxiestraat 11, 2800 Mechelen, Belgium.

* Corresponding author: robin.brabant@naturalsciences.be

$\dagger$ shared first authorship
}

KEYWORDS: parti-coloured bat, Vespertilio murinus, Belgian part of the North Sea

On September 19 $19^{\text {th }}, 2014$ at 1:34am, a call sequence of a parti-coloured bat Vespertilio murinus was registered at approximately five kilometers off the Belgian coastline (N 51 21.40 , E $\left.3^{\circ} 6.06\right)$. This is the first observation of the species in the Belgian part of the North Sea. The meteorological conditions during the time of the recording were good, with a temperature of $18.6^{\circ} \mathrm{C}$, a moderate easterly wind ( $\left.3 \mathrm{Bft}\right)$ and no precipitation.

The parti-coloured bat was detected from the Belgian research vessel 'Belgica' equipped with an automated acoustic SM3BAT recorder (wildlife acoustics Inc., Massachusetts, USA). The device records the echolocation calls of bats (between 0 and $126 \mathrm{kHz}$ ), from shortly before sunset to shortly after sunrise, hence allowing study of the spatio-temporal distribution patterns of bats in the Belgian part of the North Sea. The recordings were processed with the software programs SonoChiro (version v3.3.2; Biotope, France) and Batsound (version v1.3.1; Pettersson Elektronik, Sweden) to extract the echolocation calls of bats and to aid the identification to the species level. Every registration has a timestamp that is linked to the time and GPS registration of the ship, allowing determination of the exact time and location of observation.
The acoustic detector was operational during 84 nights in autumn 2014 (from 11 August until 5 December) and 76 nights in spring/summer 2015 (from 16 March until 22 July). This record was the only detection of a parti-coloured bat during this study.

The parti-coloured bat was registered for a period of 20 seconds, during which the call was recorded 60 times. This suggests the specimen was not just passing by the vessel. The call sequence is typical for an individual crossing an open biotope but some foraging calls (or buzz) are also noticeable. The intense activity suggests the parti-coloured bat was attracted by the vessel while passing by, where it most likely foraged for a short period of time.

The sonogram of the registered parti-coloured bat call shows an average frequency of maximum energy at 25.4 ( \pm 0.30 standard deviation) $\mathrm{kHz}$ and an average duration of a single call of about $20( \pm 1) \mathrm{ms}$ (Fig. 1, Table 1), which is typical for the parti-coloured bat $[1,2]$. The rate of repetition of the calls is known to be about $5 \mathrm{~Hz}$ [1], which fits our recording.

The parti-coloured bat is a Palearctic species occurring over an extensive geographic area [1]. It is widely distributed from the Asiatic Pacific coast through Siberia to eastern, northern and central Europe in the west [2]. The western limit of its regular distribution lies in eastern France, 
TABLE 1

Average, standard deviation, maximum and minimum values of the key variables of the 21 most distinctive calls in the sequence of the registered parti-coloured bat specimen. FI = initial frequency; FT = end frequency; $\mathrm{FME}=$ frequency of maximum energy.

\begin{tabular}{|l|ccccc|}
\hline & FI $(\mathrm{kHz})$ & FT $(\mathrm{kHz})$ & FME $(\mathrm{kHz})$ & Call duration $(\mathrm{s})$ & Intervals between two calls (s) \\
\hline average & 27.45 & 23.09 & 25.41 & 0.020 & 0.231 \\
standard deviation & 0.91 & 0.23 & 0.30 & 0.001 & 0.07 \\
maximum & 30.42 & 23.92 & 25.83 & 0.027 & 0.48 \\
minimum & 24.30 & 22.76 & 23.88 & 0.0177 & 0.10 \\
\hline
\end{tabular}

Switzerland and southern Scandinavia (Fig. 2)[1]. The species is rare or absent in westernand southern Europe, however vagrants have been recorded far outside its normal range, e.g. Tuscany [3], Spanish Pyrenees [4], Isle of Arran [5], Shetland Islands [5] and even oil rigs in the North Sea [6]. The species is known to migrate long distances of up to 2000 kilometers from Scandinavia and Central Europe to more temperate regions of Western Europe, and back [7,8,9]. Observations at the western limit of its distribution are linked to autumn dispersion and probably also hibernation [10]. For more information about the ecology of Vespertilio murinus, we refer to RYDELL \& BAAGØE (1994) [1].
In Belgium, the parti-coloured bat has until now been recorded 41 times, including eight in 2014. The majority of those records were made in September and October, but there are also records in Belgium from February, March, April and June. The first observation was made in 1989 in the coastal community Blankenberge. A second record was made in the year 2000, and from 2006 onwards there is an increase in the number of records. Nine records were made with an acoustic detector, other records concern found (dead or injured individuals) or captured specimens or were sightings at a roosting location. Only three of the eight observations in 2014 were recorded by a detector. Most of the

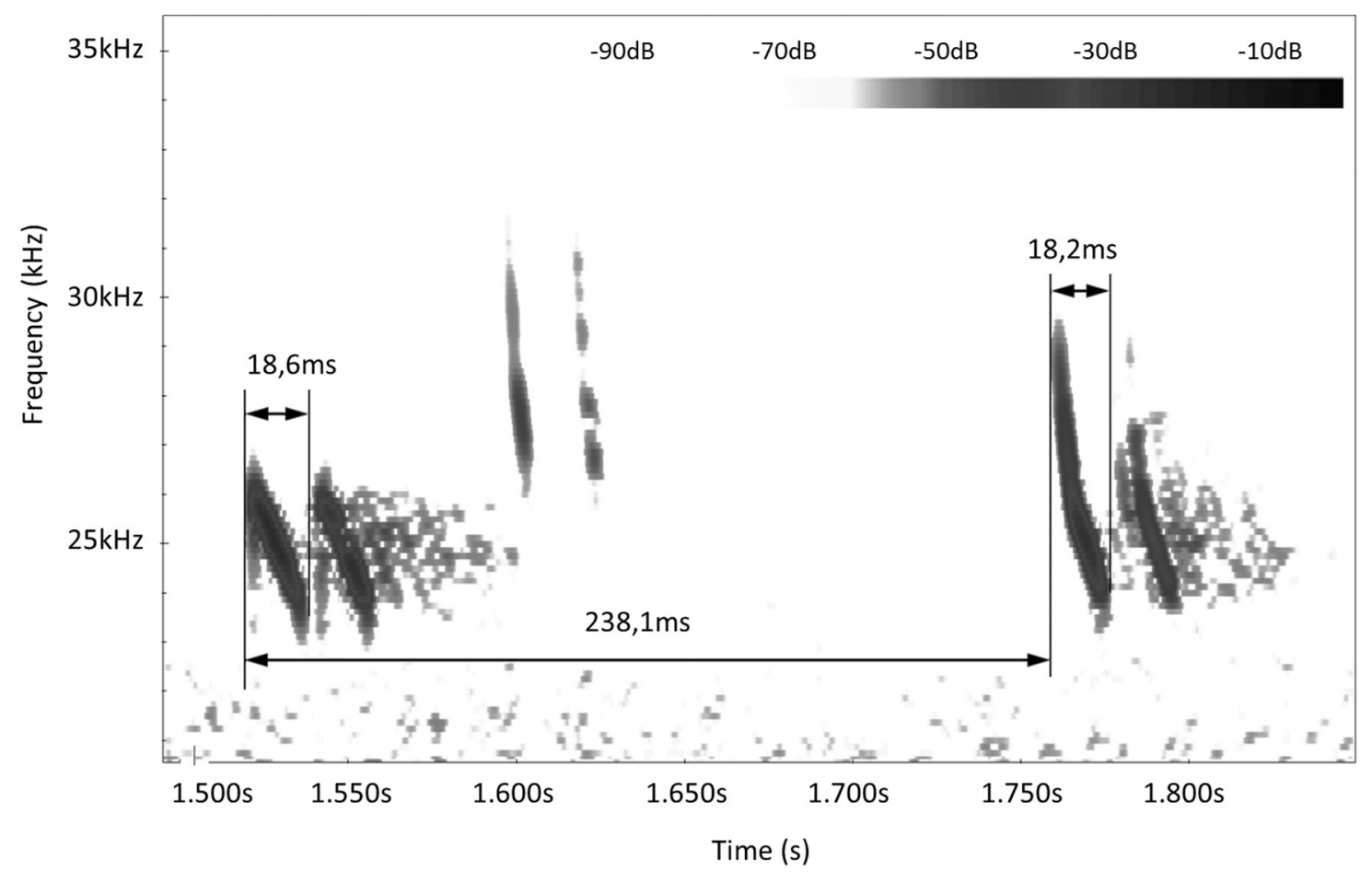

Fig. 1. - Sonogram of the parti-coloured bat Vespertilio murinus detected in the Belgian part of the North Sea. 
Belgian observations were made onshore along the coast and along large riverbeds [11]. Similar to the Belgian records, 11 of the 24 observations of this species in the Netherlands between 1977 and 1995 were obtained from coastal localities [12]. Forty specimens were detected near the Swedish coast in 2005, 2006 and 2008 [13,14]. The parti-coloured bat has previously been detected offshore in the North and Baltic Seas. Three specimens were found on oil rigs in the Dutch part of the North Sea, once in 2004 and twice in 2006, at 69, 48 and $124 \mathrm{~km}$ from the coast [6]. Our observation hence contributes to this data series with increasing numbers of offshore observations. The species was, however, not recorded during an extensive study in the Dutch part of the North Sea [15], stressing the rarity of offshore observations as yet.

Our record of the parti-coloured bat at sea and other recent observations in Belgium may be considered indicative of an increased number of specimens in our region. Together with the reported records of specimens in e.g. the Spanish Pyrenees [4] and Italy [3], this suggests the species is extending its range of distribution to the West. The IUCN red list [16] also reports expanding populations in some part of the species' distribution range, for example in Denmark and the Netherlands. On the other hand, the contribution of improved methods of detection (e.g. acoustic techniques) and an increased search effort (both in time and space) also very likely contributed to the increased number of detections of the parti-coloured bat. For the Belgian records, this is, however, unlikely as only nine of the in total 41 records were done with an acoustic recorder. Of the eight records from 2014, only three were made with an acoustic detector. More extensive studies are indispensable to any unambiguous conclusion on the real status of the parti-coloured bat in southwestern Europe.

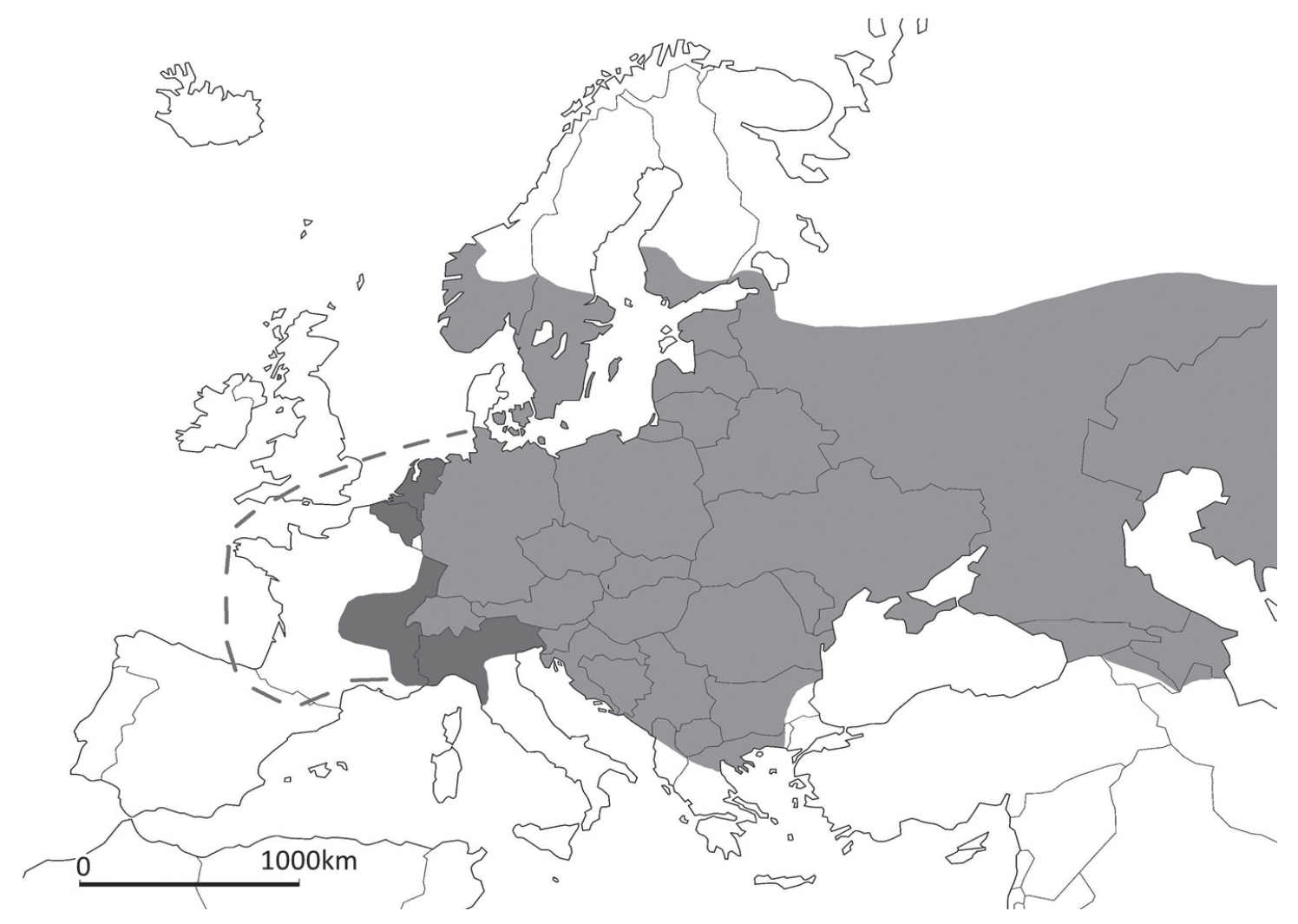

Fig. 2. - Distribution range of the parti-coloured bat Vespertilio murinus with indication of its breeding area (light grey) and its migration area (dark grey). The dotted line indicates the area where migrating individuals have been observed (adapted from ARTHUR \& LEMAIRE 2015 [10] and www.eurobats.org [2]). 


\section{REFERENCES}

[1] Rydell J \& BAAGØE HJ (1994). Vespertilio murinus. Mammalian Species, 467: 1-6.

[2] http://www.eurobats.org/about_eurobats/ protected_bat_species/vespertilio murinus?mode= print [visited on June 7th, 2015].

[3] Dondini G. \& Vergari S (2015). Range expansion? First record of parti-coloured bat (Vespertilio murinus Linnaeus, 1758) in Tuscany, Italy. Barbastella, 8(1).

[4] Alberdi A, Aihartza J, Albero J, Aizpurua O, López-Baucells A, Freixas L, Puig X, FLAQUER C \& GARIN I (2012). First records of the parti-coloured bat Vespertilio murinus (Chiroptera: Vespertilionidae) in the Pyrenees. Mammalia, 76: 109-111.

[5] Haddow J \& Goeckeritz C (2011). A particoloured bat Vespertilio murinus found on the Isle of Arran. Unpublished record.

[6] Boshamer JPC \& BeKKer JP(2008). Nathusius' pipistrelles (Pipistrellus nathusii) and other species of bats on offshore platforms in the Dutch sector of the North Sea. Lutra, 51 (1): 1736.

[7] BAAGØE HJ (2001). Vespertilio murinus Linnaeus, 1758 - Zweifarbfledermaus. In: KRAPP F (ed) Handbuch der Säugetiere Europas. Aula Verlag, Weibelsheim, Germany: 473-514.

[8] Hutterer R, Ivanova T, Meyer-Cords C \& RODRIGUES L (2005). Bat migrations in Europe: a review of banding data and literature. Naturschutz und Biologische Vielfalt, 28: 1-176.

[9] Krapp F \& Niethammer J (2011). Die Fledermäuse Europas. AULA Verlag, Wiebelsheim, Germany.

[10] ARTHUR L \& LEMAIRE M (2015). Les chauvessouris de France, Belgique, Luxembourg et Suisse; Coll. Parthénope, Biotope édition, Mèze, NHBN, Paris.
[11]FORGET F \& VANDENDRIESSCHE B (2010). First observations of the parti-coloured bat, Vespertilio murinus Linné, 1758, in the southern part of Belgium. Review of its status in Belgium and neighbouring countries. Le Rhinolophe, 18: 37-41.

[12] Hollander H \& Limpens HJGA (1997). Tweekleurige vleermuis Vespertilio murinus (Linnaeus, 1758). In: LiMPENS H, MOSTERT K \& BONGERS W (eds), Atlas van de Nederlandse vleermuizen; onderzoek naar verspreiding en ecologie, KNNV Uitgeverij, Utrecht, The Netherlands: 204-209.

[13] Ahlèn I, Bach L, BaAgøe Hu \& Petterson J (2007). Bats and offshore wind turbines studied in Southern Scandinavia. Swedish Environmental Protection Agency, $37 \mathrm{pp}$.

[14] AHLÈN I, BAAGØE HJ \& BACH L (2009). Behavior of Scandinavian bats during migration and foraging at sea. Journal of Mammalogy, 90(6): 1318-1323.

[15] Lagerveld S, Jonge Poerink B, Haselager R \& VERDAAT H (2014). Bats in Dutch offshore wind farms in autumn 2012. Lutra, 57(2): 61-69.

[16]Hutson AM, Spitzenberger F, AUlAGnier S, Coroiu I, Stubbe M, Ariunbold J, BUUVEIBAATAR V, DORJDEREM S, MONKHZUL Ts, OtgONBAATAR M \& TSOGBADRAKH M (2008). Vespertilio murinus. The IUCN Red List of Threatened Species 2008: e.T22947A9400623. http://dx.doi.org/10.2305/IUCN.UK.2008. RLTS.T22947A9400623.en, downloaded on 7 July 2015.

Received: July 24th, 2015

Accepted: January 12th, 2016

Branch editor: Johan Michaux 